\title{
Minimally invasive aortic valve replacement through a right anterior minithoracotomy 306
}

\author{
Durgaprasad Reddy Baluredy*, Vikas Singarajipura Ramakrishna, Mayuri Stristava, Subhash Kumar Kadim \\ From World Society of Cardiothoracic Surgeons 25th Anniversary Congress, Edinburgh \\ Edinburgh, UK. 19-22 September 2015
}

\section{Background/Introduction}

The Aortic valve has been traditionally approached through a median sternotomy. However, significant advances in technology have allowed for Aortic valve surgery to be performed using progressively smaller incisions including the minithoracotomy and hemisternotomy.

\section{Aims/Objectives}

To review the results of minimally invasive aortic valve replacement (AVR) through a right anterior minithoracotomy.

\section{Method}

From July 2011 to January 2014, a total of 84 patients with isolated aortic valve disease (rheumatic in 62 patients, degenerative in 14 patients, congenital in 8 patients) underwent AVR through a right anterior minithoracotomy approach in the third intercostal space with a groin incision for femoral cannulation.

\section{Results}

The mean age was 41.4 years (ranging from 19 to 74 years). 58 patients were male. Mean duration of cardiopulmonary bypass time and aortic cross-clamp time was $(82 \pm 23)$ minutes and $(53 \pm 16)$ minutes, respectively. 2 patients required conversion to median sternotomy. The mean hospital stay was $4 \pm 1$ day. Follow-up was performed in all patients for a period of $15 \pm 6$ months postoperatively. A good recovery was obtained in all patients.

\section{Discussion/Conclusion}

Minimally invasive aortic valve replacement though the right anterior minithoracotomy approach is safe and feasible with reduced postoperative recovery time.

Department of Cardiothoracic and Vascular Surgery, Vydehi Institute of Medical Sciences and Research Centre, Bangalore, Karnartaka, 560066, India
Published: 16 December 2015

doi:10.1186/1749-8090-10-S1-A53

Cite this article as: Baluredy et al:: Minimally invasive aortic valve replacement through a right anterior minithoracotomy 306. Journal of Cardiothoracic Surgery 2015 10(Suppl 1):A53.
Submit your next manuscript to BioMed Central and take full advantage of:

- Convenient online submission

- Thorough peer review

- No space constraints or color figure charges

- Immediate publication on acceptance

- Inclusion in PubMed, CAS, Scopus and Google Scholar

- Research which is freely available for redistribution 